\title{
Emperor Julian, an appropriated word, and a different view of 4th-century "lived religion"
}

\begin{abstract}
That the Greek word "Hellenismos" was used in antiquity to signify the broad concept of a "pagan religion" has long been an accepted notion in studies of the 4th-century Roman Empire despite the fact that the term was not value neutral. A word initially designed to wound, it had been coined during the tense time of the Maccabean period, where it was deployed by Jews to smear the identity of Jewish friends and neighbors for "acting Greek" and, six hundred years later, was similarly used by Christians in the Eastern Mediterranean, who used it to denigrate their own fellow believers for what they deemed to be an excessive accommodation to Roman ways. That situation changed during the mid-4th century when the Emperor Julian - raised a Christian but vilified by churchmen as an "apostate" - described his beliefs with the word "Hellenismos" in a letter sent to a pagan priest. Although it has been suggested that this document was forged, based on Julian's puzzling use of the term, this chapter argues for the letter's authenticity. I propose that Julian appropriated a known slur in order to transform it into a positive idea and suggest that it was Julian's effort to embrace a Christian faith grounded in pluralistic Greek and Roman values that ultimately earned him his infamous sobriquet.
\end{abstract}

\section{Introduction}

On or around February 19, 362, the stone architrave of a building was hoisted into place near the Roman city of Bostra. ${ }^{1}$ Today, walled above a doorway in the nearby

\footnotetext{
1 I would like to thank the volume's editors, the organizers of the conference in Eisenach, Germany, for their invitation in April 2017, their generous support and, above all, for their encouragement in my research. My thanks, as well, to all the participants for such productive conversations before, during, and after the sessions. I also need to express my gratitude to my graduate research assistant, Joel Cerimele, at Saint Louis University for helping with bibliographic matters and editing. Finally, although a full re-evaluation of Julian's reign would take an entire book, I believe that a succinct, targeted study of a specific topic can still be helpful for pointing out potential new directions; for that reason, the bibliography here is concise but by no means exhaustive.
}

Ә Open Access. (C) 2020 Douglas Boin, published by De Gruyter. (c) BY-NC-ND This work is licensed under a Creative Commons Attribution-NonCommercial-NoDerivatives 4.0 International License.

https://doi.org/10.1515/9783110557596-025 
Syrian village of Umm Ir-Rammân, it measures slightly more than one meter long, some forty inches, and it commemorates in five short lines, carved in Greek, the performance of sacrifices and the renovation of a local temple. Many citizens in Bostra, in the province of Roman Arabia (modern Syria), were perhaps justly impressed and grateful for these expensive gifts. The man under whose authority the project took place was credited in the inscription's opening lines; he was Rome's imperator and newly proclaimed Augustus, Flavius Claudius Julianus, Emperor Julian (Conti 2004, 59: VII.1.1 Arabia, no. 1). ${ }^{2}$ Julian's policy of supporting the life of the empire's shrines, temples, and sanctuaries of traditional Mediterranean worship would earn him few Christian admirers.

Temples and sanctuaries had lived many lives by the time the Roman Empire reached Julian's day in the mid-4th century CE. For centuries, going back to the Republic, town people had seen sacred buildings erected; many had also watched them fall into disrepair. Later generations watched them be rebuilt. The people of the empire had seen this cycle of renewal, renovation, and revival many times before. Yet for some historians, the actions which the Emperor Julian took during his short, three-year reign, such as the decision to rebuild in Bostra, are still shocking enough to deserve extra scrutiny. Coming almost a generation after the Edict of Milan, a momentous decision that brought Christians out of the legal shadows, Julian's support for the old traditions of Rome has seemed, to some ancient and modern commentators alike, like a vain attempt at "revival" in the face of Christianity's increasing social successes. ${ }^{3}$ Even in antiquity, judgment could be harsh. The fact that Julian had been raised a Christian gave rise to claims by some followers of Jesus that the emperor had "apostatized", or renounced, his faith. ${ }^{4}$

Julian's own words have not helped his cause (Rosen 2006; Goldsworthy 2003, 143). The emperor's archives, one of the most extensive literary treasure chests to survive from Rome's imperial palace, shed light on a highly-educated man from a wealthy political family, whose far-reaching yet complicated political, diplomatic, cultural, and military decisions provide a fascinating look at

2 The stone measures $31 \times 103 \mathrm{~cm}$ and the full text, including the local dating formula in line five, is translated from Conti's publication as follows: "In the reign of Flavius Claudius Julianus, imperator Augustus, sacrifices were renewed and the temple renovated and hallowed in the 5th day of Dystrus in the (local year) 256 [19 February $362 \mathrm{CE}$ ] (Epi krateseos Fl[avio] Kl [audiou] Ioulianou / autokratoros Augoustou / anithe ta iera kai anoikodo/methe kai aphierothe o na/os, en et(ei)sns, Dus[t]rou e.)".

3 Ammianus Marcellinus Res Gestae 22.5.2 (restituere). For evaluations of Julian's reign along these lines, Watts 2015, 109-126, with 123-124 (“revival”); see also Bowersock 1978. For another presentation, Nesselrath 2013.

4 Greg. Naz. Or. 4.1 (“apostate”). For context, see Elm 2012, 336. 
how early Christianity affected the upper echelons of 4th-century society. Whereas much "patristic" literature can be looked at with an eye towards the history of asceticism, evangelism, or homiletics, the emperor, raised in a Christian house, gestures towards a world of religious pluralism in flux and of Christians themselves locked in social debates about their faith. In one speech, assessing the widespread cultural importance of Helios, the emperor boldly claimed he was a "follower", or perhaps supporter, of the god. ${ }^{5}$ In another text, written in response to followers of Jesus who read the Genesis story and assumed its literal truth, he was ruthlessly savage, mocking their inability to specify in what language the serpent spoke to Adam and Eve. ${ }^{6}$ And in a third document - a letter, written to a priest of Asia Minor in perhaps June of 362 he articulated a political vision that, on its surface, seemed to relish the idea of excluding Christians from the imperial community. Citizens who did not find a way to support the civic cults, the emperor explained, were to be counted among the "atheists". 7

In that letter, the emperor discussed his ideology using a singularly fascinating word, Hellenismos, a concept which scholars have almost unanimously translated with the stately English noun "Hellenism". ${ }^{8}$ I will offer a different translation for this term in a moment; but before I do, I should say that that one English word has become something of a lasting brand of Julian's vision for the mid-4th-century empire. And yet, amid the dizzying number and wide geographic range of temple, statue, and sanctuary dedications that date to the emperor's rule, like the one commemorated at Bostra in February 362, the Greek word appears nowhere in the epigraphic record. If Julian had hoped to articulate and enforce an empire-wide set of traditional worship practices to counter Christianity's rise, why is his powerful branding statement absent from the material evidence?

5 “opados", Julian, Or. 4 in Wright 1913, 352. It is worth keeping in mind that Helios appears in many Jewish synagogue mosaics which have been dated to the 4th through 6th century CE. This evidence suggests that a non-Christian community could speak the visual language of the sun god while at the same time not betraying their monotheistic beliefs.

6 Julian, Contr. Gal. in Wright 1923, 323, discussed in Greenblatt 2017, 75.

7 Julian, ep. 22 in Wright 1923, 69. I have kept this discussion of Julian's writing succinct since it is background to my study, not the focus. For an alternative numbering of the letters, see Bidez 2004. Some believe this letter is a forgery because of its sketchy transmission history; see Rosen 2006, 301. I address this point below and in another forthcoming article, also referenced below.

8 "Hellenismos", Julian, ep. 22 in Wright 1923, 66-67. 


\section{Overview of the argument}

Following the theme of the Eisenach conference, this chapter explores one aspect of "lived religion" in antiquity, focusing on the life of emperor Julian in the mid-4th century CE. In it, I argue that Julian's concept of Hellenismos is missing from the material record because, in Christian contexts of Julian's day, it did not yet carry the broad, sweeping, positive connotations which Julian hoped to associate with it. The problem lay in the fact that Julian died less than a year after writing this letter at a time when the word he used was still largely understood to be a pejorative one by many 4th-century Christians.

Among both Jewish and Christian audiences, the term had never exactly been value neutral, not even at its inception. As a word carefully designed to wound, it had been coined during the tense time of the Maccabean period, where it was deployed by Jews to smear the identity of Jewish friends and neighbors for "acting Greek" (Schwartz 2001, 32-35). Because of that Second Temple context, I have proposed that Hellenismos was a word whose faithbased, insider nuances had a fairly limited reach even in subsequent Christian conversations, notwithstanding the word's eventual ability to declare a general affinity for Greek culture in conversations during the 2nd-century Roman Empire onward. Followers of Jesus who savaged their own peers for "acting too Greek" - the word is more effectively translated as a gerund, or verbal noun were the sad inheritors of this strident debate from five centuries before, when the Second Temple still stood (Boin 2014).

Julian's radical desire to encourage 4th-century Christians to "act Greek" by embracing, indeed, appropriating this once hurtful word, was not, then, an attempt to voice to the empire's sixty million inhabitants a coherent vision that could stand in opposition to Christianity. ${ }^{9}$ A word of more limited reach, something akin to jargon used during in-house Christian conversations among Ignatius of Antioch, Eusebius, Athanasius and others - it was an epithet that would come to have a certain fascination for Julian when he decided to clean off its harmful connotations and embrace it. Indeed, understanding Julian's mid-4th century social setting is a crucial first step in appreciating the emperor's decision to transpose its meaning. Julian's wish to switch the code in this ferocious Christian conversation, wresting a term of disparagement away from

9 Scholars who would characterize Julian's vision as a forceful, deliberate response to the successes of the Christian church, to my mind, miss the nuance in Julian's language here; for an example of this approach, which for me remains too mired in dichotomous reconstructions of the 4th century, see Greenwood 2017, 20-21 (“a deliberate counter to Christianity"; a "statesupported paganism" to match Constantine’s "state-supported Christianity”, 21). 
hard-liners, may have been an attempt to turn the tables in the debate about who had the power to define what it meant to be a "real Christian" and who would be slandered for having purportedly crossed non-negotiable cultural divides.

A motley group even during Julian's time, as is well illustrated by the extent of their theological divisions, Christians of the mid-4th century were certainly divided socially and politically. They were engaged in debates about whether to participate in Rome's continuing civic sacrifices, whether to attend the arena and the games where the gods were honored, and even whether it was necessary to worship with other Christians in public or at home. All of these complicated social components of a Christian identity, in the aftermath of Constantine's reign, had continued to feed the mid-4th-century conversation about who among the group deserved to be called a "Christian" (Boin 2015, 89-128). Social divisions like these, in addition to ongoing theological ones, would certainly shed light on what one contemporary historian wrote about Julian's own lived reality: "Experience had taught him that no wild beasts are such dangerous enemies to a man as Christians are to one another."10

This chapter develops a snapshot of social, cultural, and political disagreement among Rome's 4th-century Christians in two ways. First, it argues that emperor Julian's rule marked a transformational shift in Roman politics because, for the first time, a man who had been raised a Christian was reclaiming the disparaging epithet of "Hellenismos," turning it against his detractors, and asserting it as a positive model for Christian engagement with Roman culture. Second, it explores how the "presence of an absence" in the material record can, paradoxically, help support this same historical reconstruction.

In the end, this chapter suggests that historical analysis built on Julian's supposed "apostasy" or even on his alleged "hatred for Christians" are too imprecise, or theologically biased, to be useful. Julian - an emperor born in a Christian household, a lector in the church, and conversant in long-running social identity disputes within Christianity - may more profitably be studied for the way his own "lived religion" found innovative ways to seek out and promote a different kind of Christian identity in the decades after the Edict of Milan. ${ }^{11}$ These may have been insider debates among Jesus' followers, but they were not inconsequential. At their essence were large, pressing questions about the health of the empire's pluralistic society. Christians had been full participants in that pluralistic endeavor from the first generation of the Jesus movement, but the pressing political conversation after Constantine was whether

10 Ammianus Marcellinus 22.5.1 (trans. by W. Hamilton [London: Penguin Books, 1986] 239). 11 Socrates, Church History 3.1 (lector at Nicomedia). 
Christians would continue to support Rome's long-established ideals of toleration or if factions of Christians would insist on abandoning it. I would like to begin my discussion with what the material culture evidence can tell us.

\section{Statement of the problem: the absence of evidence from material culture}

This chapter opened with the vignette of the building being erected in Roman Bostra because it helps visualize how traditional religion was lived in the mid4th century. It also helps us eavesdrop on a wider conversation about the language of contemporary religious places and practices, such as the ideas of "shrines", "temples", even "renovation". For inscriptions, as Antony Eastman has described it, communicate, not only in what they say, but in the decisions that may have led to "choices of script, scale, location, spatial organization, letter style, clarity and legibility"; these, too, are aspects that shaped their message. ${ }^{12}$ Eastman's observations are worth keeping in mind as we consider inscriptions from Julian's age which relate to worship and belief.

During Julian's short reign, dedications in Maktar in modern Tunisia and Timgad in modern Algeria were erected by imperial cult priests, the flamines perpetui to restore local buildings. ${ }^{13}$ In Asia Minor, Julian was declared the "greatest and most divine emperor"14 and was praised for overseeing a reign which was expressive of the "highest love for his fellow human beings." $15 \mathrm{He}$ was regaled with the language of Rome's imperial cult, with dedications to the gods made "on behalf of his well-being." ${ }^{16}$ In Thessaloniki, the emperor himself was called theophilestatos, a man who could claim to be "the most loved by the gods"; the superlative is an unquestioned rarity in the epigraphic record. ${ }^{17}$ And, at many road markers in Roman Syria, such as three from Jerash in

12 Eastman 2015, 1-11, with the quotation from page 1; also good on these points is Cooley 2012, 220-228.

13 “fl(amen) p(er)p(etuus)”, line 7, Byzacena (Maktar, Tunisia) no. 153 at Conti 2004, 104; “fl(amine) p(erpetuo)", line 7, Africa (Timgad, Algeria) no. 174-175 at Conti 2004, 175-176.

14 "ton megiston kai theiotaton Autokratora Augouston", lines 7-8, Asia Minor no. 34 at Conti 2004, 83, from Iasos, with extensive bibliography.

15 "philanthrootaton basilea", lines 3-4, Asia Minor, no. 34 at Conti 2004, 84.

16 "pro salute imp(eratoris) ... ”, line 2, North Africa, no. 132 at Conti 2004, 150. The inscription was found at Bou Arada, Tunisia, and is currently in the archaeological museum there. 17 "theophilestatou ... Claudio Iouliano", lines 1-8, Macedonia, no. 54 at Conti 2004, 96. The inscription is Archaeological Museum of Thessaloniki inv. 7359. 
modern Jordan, Julian was invoked in the context of the greatness of "one god", a phrase which, in Nicole Belayche's view, says very little about the supposed spread of monotheism and much more about the cultural practice of how to acclaim the emperor's unique stature. ${ }^{18}$

The clearest indication that any inscription comes to giving a name to this diverse "religious system" of the ancient world comes from a text dedicated in North Africa. In it, Julian is praised for his contributions to the world of "Roman worship", "Ro|[manae] re|ligion[is]". 19 This inscription comes the closest of any surviving piece of material culture in trying to fix a definitive label on the cultural world of worship and belief that dominated in the ancient Roman Mediterranean. Even if we choose not to accept the editor's restoration note his preference for the genitive singular, religionis, instead of the plural the choice of the word, religio, was hardly a radical or unorthodox one. The Latin concept of religio, or a "socially-acceptable form of worship", was the same flexible, albeit contested ideal that had kept Rome's social fabric together for centuries, even in the heart of the constitutional reforms enacted by Constantine and Licinius, in 313 (Kahlos 2007a; 2007b, 93-112; Beard, North and Price 1998, 211-44).

To sum up, the epigraphic evidence is clear. Neither Julian nor any local figure throughout the empire ever made reference to the emperor's alleged program of Hellenismos in monuments or dedications set up at temples, shrines, or sanctuaries anywhere during Julian's reign. So how should historians account for this silence (in the material record) when Julian's own voice (in the textual record) seems adamant that Hellenismos was his passionate concern? One scholar has gone as far as now proposing that Julian's letter must be a forgery (Van Nuffelen 2002, 138-139). In the remainder of this chapter, however, I would like to move this conversation in a different direction.

\section{A discussion of method: material culture and the presence of an absence}

What does it mean for something to be missing from the material record? One way of understanding of how material culture works would deduce that, because the word Hellenismos does not appear in the Greek epigraphic record of

18 "Eis theos", line 1, Oriens, no. 3, 7, and 8, at Conti 2004, 60; see also Belayche 2010, 164. 19 Lines 10-12, Africa, Numidia (El Madher, Algeria), no. 167 at Conti 2004, 170-171, with bibliography. 
Julian's day, the concept must have been far less socially, culturally, or historically important at the time than historians have made it out to be. I do not ascribe to this seemingly straight-forward, deductive way of interpretation. Instead, I follow the lead of theorists like Scott Hutson and Ian Hodder who have assembled a more carefully calibrated lens with which to examine these kinds of questions. For them, it is "the 'presence' of an absence" here which calls out to be the "focus of research" (Hodder and Hutson 2003, 175).

Although safe, traditional, and conservative methodologies would not try to make judgments from the "absence" of evidence, I believe Hodder and Hutson are correct in drawing a distinction between an argument from silence and an argument about silence. Silences matter, and in their writing Hodder and Hutson provide a useful illustration by asking readers to imagine studying an ancient society whose people are famous, archaeologically and art historically, for painting their ceramics. A historian of this hypothetical culture could ask research questions that are based around the obvious issue, like "why pots are decorated," but a subtler level of analysis might also want to explore broader patterns in the material record, asking, for example, "why only pots are decorated." As the two writers explain:

This is... a matter of identifying the particular framework within which action has meaning. If pots are the only type of container decorated in one cultural context, this is of relevance in interpreting the meaning of the decoration... Archaeologists need, then, to be alive to difference and absence.

(Hodder and Hutson 2003, 175-176)

Following Hutson and Hodder's lead, in my work, specifically, I have explored how these theories and methods can be applied to questions about early Christian material culture in the ancient Mediterranean (Boin 2013, 41-43). ${ }^{20}$ One guiding principle for me has been to explore how social stigma can explain, historically, those key moments in Roman history when we should expect to see Christians in the material record but do not.

There is, for example, no explicitly Christian art that can be dated to the 1st or 2nd century CE, and it takes nearly two centuries from Jesus' execution by the Roman government for the remains of a Christian worship space (what would come to be called a "church") to appear in the archaeological record, at Dura Europos. Instead of falling back on theological crutches to explain the peculiarities of this evidence - a supposed aversion to "graven images" or pious presumptions about the poor or humble origins of Jesus' followers - my work

20 See also Boin 2015, 40-43, on the irrelevance of the Second Commandment and on wealthy members of the early movement. 
has tried to explain these silences by pointing to social factors. Foremost among them has been the issue of how individuals "managed" the stigma that was associated with their identity as one of Jesus' followers, both before and after the Edict of Milan (Goffman 1963). Although the nature of stigma could and often did change depending on social circumstances and the unique nature of social, political, and cultural developments across the centuries, this work, in general, has helped to shift the focus away from instances of overt social conflict, such as that promoted by the martyr stories, towards the reconstruction of a social world where Jesus' followers made their place for themselves through passing, covering, and other creative, moderate ways, balancing their Roman identities with their Christian commitments.

What is important to conclude here is that the absence of Hellenismos from the epigraphic record - in the narrow window from 361-363 CE - does not have to be treated as a problem for understanding the context of Julian's letter to Arsacius. Perhaps the decision by a Greek or Roman priest or local benefactor not to use the word might have been an act of negotiation to build a more inclusive public space, a realm of open-ended performance where rigid identity labels were shunned in favor of specific demonstrations of religious behavior. If so, many Christians may have responded comfortably to the invitation, creatively finding ways to live alongside this non-Christian culture. We also cannot rule out that many worshipers of traditional Greek and Roman religions, being unfamiliar with the long history of the word in Jewish and Christian circles, chose not to use the term Hellenismos because they simply did not understand the sectarian way that Julian was using it. Consequently, there would have been no reason to include the word on their dedications of a new statue or a restored temple, especially if they wanted to avoid wading into the details of an intra-Christian debate. In short, many things can be left out of the historical record and for many reasons, but silence can be meaningful, too.

\section{From stigma and silence}

\section{to an act of appropriation and transposition}

The picture from Julian's perspective looks slightly different. The emperor's decision to appropriate the originally-negative idea expressed by Hellenismos, or “acting Greek,” as a positive model for 4th-century Christian behavior had a long precedent. The process by which Christians had negotiated their place in the Roman Empire began with their decision to appropriate the derogatory word "Christian" itself, a word that Jesus' followers embraced from their detractors in 
the late 1st or 2nd century (Treblico 2012, 3-4, 272-297), and the process by which Julian later came to embrace the concept of Hellenismos would have sat perfectly within the long, complicated story of Christian identity management. That is the topic I will explore in this last section. My argument is that it was the silence of many moderate Christian voices throughout Rome's history that ultimately inspired Julian to articulate his vision for the 4th century empire.

As the literary legacy of the word Hellenismos suggests, throughout the 2nd through 4th centuries CE, many of Jesus' followers did want to be socially integrated into the empire, not stand apart from it (Boin 2014). And some perhaps did want to ensure, like Julian, that Christians would hold one place among many in Rome's diverse world. In antiquity, however, very few leaders, if any, ever rose to champion these people's voices - just the opposite, in fact. For two centuries, the Christian men and women who held these views were pilloried by their more zealous peers for "acting too Greek." Eusebius stands at the front of this group for his passionate attempt to warn followers of Jesus, in the early 4th century, that "being openly Christian" (Christianismos) was not about "acting like a Greek (Hellenismos)." ${ }^{21}$ At the 4th century's end, this internal Christian conversation was ongoing, with bishop John Chrysostom cautioning his congregation not to fall into the same cultural snares: of going to banquets, races, games, or temples - which he associated with acting "like a Greek". 22

It is the mounting weight of this stigma, brought to bear in the years after the Edict of Milan - when everyone could act Christian however they wished which caused a crisis for many 4th-century Christians and which led to Julian's own writing. As the charge of "acting Greek" picked up during this time, foisted by Eusebius, in particular, Julian took the derogatory word and transformed it in his plan for greater social integration amongst the empire's Christians:

My vision that Christians be able to 'act Greek' without fear of being mocked (Hellenismos) is not yet having the success I wish, and it is the fault of those who profess it. For the matter of the gods is on a splendid and magnificent scale, surpassing every prayer and every hope. ${ }^{23}$

Although it may seem stretched, support for this interpretation could come from the fact that the emperor never named his Christian political opponents as

21 Eusebius, Demonstratio Evangelica 1.21; also reiterated at Eusebius, Praeparatio Evangelica 1.5.12.

22 A good example is John Chrysostom, Catechesis 6.15-16; Sandwell 2007, 66-75, discusses the meaning of "Hellene" within a positive cultural frame of reference. I have suggested (Boin 2014) that Chrysostom is using it with the negative, in-group Maccabean intent.

23 Julian, ep. 22 in Wright 1923, 66-67, with my elaboration. 
"Christians". In this letter, specifically, he lumps them together as "atheists" and "impious Galileans". ${ }^{24}$ The subtlety of Julian's language would suggest that what was at stake in this debate was the reward of being able to claim the name "Christian" without needing to justify it to the self-appointed guardians of group identity. ${ }^{25}$ Further support for this reading may come from the fact that the emperor is appealing to a community whom he calls "Hellenists", a term that had a long, inside-group history in Christian circles, where the same word was used to differentiate Greek-speaking Jews from "Hebrews" during the New Testament period (Acts 6.1). In the same way that both words described members of the Jewish community, "Hellenists" and "Hebrews", Julian's recommendation - "Teach the Hellenists to contribute to public service" - may be signaling the emperor's vision for a broad, specifically-Christian form of public engagement that embraces the value of "acting Greek without fear of being mocked."26

In a contribution to a volume on rhetoric and religious identity in Late Antiquity, I explore some of the ways that linguistic reclamation can be beneficial for the people who engage in that act. ${ }^{27}$ Since I had the fortune of sharing some of that research with the conference participants in Eisenach, I would like to end this contribution by summarizing some of it here - and then expanding upon it. “A historian's job," I have written, "is not to take sides in internal identity disputes like the ones ... described in the Maccabean period or the social landscape of 4th-century Rome" (Boin (forthcoming)). When sources are characterized by examples of in-group bickering, it is incumbent upon historians to pay careful attention to those intra-group dynamics. Studying the process of linguistic reclamation can be one way to arrive at a more nuanced understanding of Rome's 4th-century social and cultural history.

Farah Godrej, in her political science research, has written about reclamation as "a tool for disarming the power of a dominant group to control one's own and others' views of oneself, to categorize oneself or one's group in a totalizing way" (Godrej 2011, 112). For Godrej, the issue of appropriation goes to the essence of owning “one's life narrative," a process which is "only meaningful if the world responds positively to this self-reconstruction, instead of denying or

24 “dussebeis Galilaioi”, Julian, ep. 22 in Wright 1923, 70-71.

25 For example, pace Kaldellis, who suggests "Galileans" is "what the Apostate called Christians to belittle them” (Kaldellis 2008, 144).

26 Julian, ep. 22 in Wright 1923, 70-71, with my translation of Hellenists for Wright's "those of the Hellenic faith" (Hellenistas).

27 This summary and other examples are taken from Boin (forthcoming), which also offers a deeper social-historical look at the details of Julian's reign and its historiography. 
ignoring the stories one chooses to tell" (Godrej 2011, 118-119). Other researchers, such as linguist Arthur Spears in his work on U.S. history, have written poignantly about how African-Americans have "defanged" the hurtful n-word to reclaim their own stories, as well (Spears 1998, 241).

What these instances of reclamation, appropriation, and transposition illustrate is a phenomenon that Judith Butler has also written about in her work: the power of language to hurt and the power of language to undo that same injury (Butler 1997, 1). In Butler's analysis, the act of taking language out of its original context and turning it into something else is what gives rise to "the basis of an ironic hopefulness that the conventional relationship between word and wound might become tenuous and even broken over time" (Butler 1997, 100). "Ironic hopefulness" might strike readers as too-modern a concept to apply to the ancients, but I do not think it is beyond the imagination to think that many 4th-century Christians might have looked to Julian for something very much like it during his short reign. It might even more accurately be called, in simple terms, "hope". And it may have been the hope that what we would call their Christianity would not be consumed by the far-different political vision of their peers.

From Paul to Julian, from the 1st century to the 4th, there is an unbroken chain of evidence that suggests Jesus' followers could and did find innovative ways to incorporate their belief in Jesus into Rome's pluralistic society. At every turn in Rome's history, however, it was that group which was written out of the history of the church. At Corinth, Jesus' followers attended sacrifices and were chastised for it. In North Africa, Christian serving the army who paid their respect to the emperor's family were called out for their behavior by men like Tertullian. In Syria, home renovators in Dura Europos remodeled a domestic residence, "making noise" at a time when other Christians felt the pressure of the local authorities (Boin 2015, 15-56); in short, the story of Christianity is replete with examples of Jesus' followers who worked within the social structures of the empire to gain political status for their group. Certainly the long history of their highly personal decisions - finding ways to be both Roman and Christian at the same time - might even suggest that Christians accused of "acting too Greek" may have been the silent majority of their own group.

That, I think, is ultimately what must have given Julian's attempt at reclamation such power. The emperor, as a Christian, was taking sides against those Christians of his day who rejected long-held Roman values, like pluralism and toleration, in their attempt to define being "Christian" in as narrow a way as possible. In this debate, Julian lost. This reconstruction of 4th-century society, with Christians throughout the empire fighting to define their religious history at the same that some Christians were growing increasingly uncompromising in 
their beliefs, nevertheless, puts the changes wrought on the empire during the late 4th and early 5th century in a much sharper focus. And as a historian, I believe Julian and his appropriation of the word Hellenismos can play a part in documenting that crucial conversation.

\section{Bibliography}

Beard, Mary; North, John; Price, Simon 1998. Religions of Rome. Volume One: A History. Cambridge.

Belayche, Nicole 2010. 'Deus deus. . .summorum maximus (Apuleius): Ritual Expressions of Distinction in the Divine World in the Imperial Period.' In One God: Pagan Monotheism in the Roman Empire, ed. Stephen Mitchell, Peter Van Nufellen. New York. 141-166.

Bidez, Joseph 2004. Julian: Lettres et fragments. Fifth edition. Paris.

Boin, Douglas 2013. Ostia in Late Antiquity. New York.

Boin, Douglas 2014. "Hellenistic "Judaism" and the Social Origins of the "Pagan-Christian" Debate', Journal of Early Christian Studies 22.167-196.

Boin, Douglas 2015. Coming Out Christian in the Roman World. New York.

Boin, Douglas (forthcoming). 'The Memory of the Maccabees, “Apostasy”, and Julian's Rhetorical Appropriation of "Hellenismos" as Signs of a Fourth-Century Intra-Christian Debate.' In Rhetoric and Religious Identity in Late Antiquity, ed. Richard Flower, Morwenna Ludlow. Oxford.

Bowersock, Glen 1978. Julian the Apostate. Cambridge.

Butler, Judith 1997. Excitable Speech: A Politics of the Performative. New York.

Conti, Stefano 2004. Die Inschriften Kaiser Julians. Stuttgart.

Cooley, Alison 2010. The Cambridge Manual of Latin Epigraphy. New York.

Eastman, Antony 2015. 'Viewing Inscriptions.' In Viewing Inscriptions in the Late Antique and Medieval World, ed. Antony Eastmond. New York. 1-11.

Elm, Susanna 2012. Sons of Hellenism: Fathers of the Church: Emperor Julian, Gregory of Nazianzus, and the Vision of Rome. Oakland.

Godrej, Farah 2011. 'Spaces for Counter-Narratives: The Phenomenology of Reclamation', Frontiers: A Journal of Women Studies 32. 111-133.

Goffman, Erving 1963. Stigma: Notes of the Management of Spoiled Identity. Englewood Cliffs.

Goldsworthy, Adrian 2003. The Last Pagan: Julian the Apostate and the Death of the Ancient World. Phoenix Mill.

Greenblatt, Stephen 2017. The Rise and Fall of Adam and Eve. New York.

Greenwood, David 2017. 'Constantinian Influence on Julian's Pagan Church', Journal of Ecclesiastical History 68. 1-21.

Hodder, Ian; Hutson, Scott 2003. Reading the Past: Current Approaches to Interpretation in Archaeology. Third edition. Cambridge.

Kahlos, Maijastina 2007a. 'Religio and superstitio: Retortions and Phases of a Binary Opposition in Late Antiquity', Athenaeum 95. 389-408.

Kahlos, Maijastina 2007b. Debate and Dialogue: Christian and Pagan Cultures, c.360-430. New York. 
Kaldellis, Anthony 2008. Hellenism in Byzantium: The Transformations of Greek Identity and the Reception of the Classical Tradition. New York.

Nesselrath, Theresa 2013. Kaiser Julian und die Repaganisierung des Reiches: Konzept und Vorbilder. Munster.

Rosen, Klaus 2006. Julian: Kaiser, Gott und Christenhasser. Stuttgart.

Sandwell, Isabella 2007. Religious Identity in Late Antiquity: Greeks, Jews, and Christians. Cambridge.

Schwartz, Seth 2001. Imperialism and Jewish Society, 200 B.C.E. to 640 C.E. Princeton.

Spears, Arthur 1998. 'African-American Language Use: Ideology and So-Called Obscenity.' In African American English: Structure, History, and Use, ed. Salikoko S. Mufwene, John R. Rickford, Guy Bailey, John Baugh. New York. 226-250.

Trebilco, Paul 2012. Self-Designations and Group Identity in the New Testament. New York. Van Nuffelen, Peter 2002. 'Deux fausses lettres de Julien l’Apostat (La lettre aux Juifs, Ep. 51 [Wright], et la letter à Arsacius, Ep. 84 [Bidez])', Vigiliae Christianae 56. 131-150. Watts, Edward 2015. The Final Pagan Generation. Oakland.

Wright, Wilmer 1913. Works of the Emperor Julian 1. Loeb Classical Library. Cambridge. Wright, Wilmer 1923. Works of the Emperor Julian 3. Loeb Classical Library. Cambridge. 